\title{
The Effectiveness of Integrated Comic Electronic Media Islamic Values on Students' Creative Thinking Ability
}

\author{
Ucca Swasti Praptiwi ${ }^{*}$, Agus Yulianto ${ }^{1}$, Ellianawati Ellianawati ${ }^{1}$ \\ ${ }^{1}$ Science Education Study Program, Postgraduate, Universitas Negeri Semarang, Indonesia.
}

DOI: $10.29303 /$ jppipa.v7iSpecialIssue.1033

\section{Article Info}

Received: October 10 $10^{\text {th }}, 2021$

Revised: December 18th, 2021

Accepted: December 22th, 2021

\begin{abstract}
Learning activities that utilize digital technology for online learning are an alternative during the COVID-19 pandemic. This study aims to determine the effectiveness of electronic comic media based on problem-based learning integrated with Islamic values to improve students' creative thinking skills. This study uses a Research and Development approach using the ADDIE model. The subjects in the study were 90 students of class VIII. Data collection techniques using research instruments with quantitative data analysis. The data collection instrument was by giving essay questions in the form of a creative thinking ability test. The study of creative thinking skills by calculating the N-gain and the significance test was carried out using an average difference test through a t-test with the help of SPSS. The results showed that the value of significance ( 2 tailed) from the two schools, namely $0.00<0.05$, then $\mathrm{H} 0$ is rejected, and Ha is accepted, so it can be concluded that there is a difference in the average creative thinking ability of the pretest and posttest both at SMP N 3 Watumalang and at SMP IT Permata Hati, which means that there is an effect of using E-Comic media in improving students' creative thinking skills.
\end{abstract}

Keywords: Electronic comic; Problem-based learning; Islamic values; Creative thinking skills

Citation: Praptiwi, U.S., Yulianto, A., \& Ellianawati, E. (2021). The Effectiveness of Integrated Comic Electronic Media Islamic Values on Students' Creative Thinking Ability. Jurnal Penelitian Pendidikan IPA, 7(SpecialIssue), 345-350. https://doi.org/10.29303/jppipa.v7iSpecialIssue.1033

\section{Introduction}

Current technological advances can be used in online learning activities as an alternative for learning activities during the COVID-19 pandemic (Nahdi \& Jatisunda, 2020). Things that can facilitate the delivery of learning materials can be done by utilizing learning media. Information conveyed through learning media can be presented more clearly, learning activities can run smoothly, learning processes and outcomes can also increase (Hamka \& Effendi, 2019). Nowadays, almost people of all cultures and ages like to read comics which is one of the most common carriers of humour (Rina, et al., 2020). One of the most popular comics among young people is Manga. The popular culture of reading Japanese comics or Manga in
Indonesia, the majority of readers are teenagers aged less than 25 years (Kirana, 2016).

Middle school students, on average, have an age range of 11-14 years, including fans of Japanese comics such as Manga. Comic reading activities can serve as a pedagogical tool that can involve students in participating in learning activities (Bessette, 2020). The most prominent advantage of the visual nature of comics in the field of education is how to read comics that are not time-bound, create a sense of comfort in reading, and students can communicate directly with the characters so that it seems as if students can be part of the comic narrative (Derbel, 2019). Attractive illustrations and simple comic language also make it easier for students to understand abstract and complex concepts (Toh, et al., 2017). The existence of this interest can trigger students to be involved in the learning

\footnotetext{
*Email: uccaswasti012@students.unnes.ac.id
} 
process, for example, to solve problems presented in learning.

Problem-based learning through comics can be used as a teaching and learning strategy by providing scenarios related to everyday life, which are then converted into comic concepts (Jamal, et al., 2019). The presentation of comics connected to students' lives can help make learning experiences more intense and create a connection between students and science questions (Affeldt, et al., 2018). In the digital era, comics can be presented in electronic comic format. Electronic comics are comics in electronic media with stories and characters owned by each character to convey the message or essence of the comic (Yuliana, et al., 2017). Electronic comics to further trigger students' involvement in learning are presented in a problembased form. Electronic comics or problem-based EComic can connect learning materials with information in the real environment through problems that exist in comics. For example, presenting daily problems related to vibration, waves, and sounds such as allergies to the larynx, ringing in the ears, bomb explosions that cause resonance, sound reflection applications, and noise cases at airports. The daily problems presented can foster students' creative ideas to solve them (Fery, et al., 2017). The ability to think creatively can make a person able to find gaps, provide alternative solutions, propose new ideas, combine ideas and propose relationships between ideas with one another (Jankowska, et al., 2019). Creative thinking is referred to as a basic skill that humans have in thinking about the science (Suratno, et al., 2019). Therefore, the best way to encourage children to think creatively is to use comics (Koutníková, 2018).

Learning activities by applying the problembased learning method are important, but integrating Islamic values in learning is no less important to implement. Science learning in schools is still minimally integrated with Islamic values, models, methods, or learning approaches. Research on the integration of Islamic values with learning materials has not been done in many fields (Purwati et al., 2018). Problem-based learning-based electronic comic media integrated with Islamic values is important. Its development can be done by presenting alternative teaching media in the form of comics that can be accessed through a line webtoon application and problems in everyday life that are integrated with Islamic values in the form of verses of the Qur'an. Examples of the integration of Islamic values in the material of vibration, waves, and sound in everyday life, such as the concept of waves in the Qur'an Surah Hud verse 43, the idea of resonance in Surah Al-Anfal verse 2, and sound reflection associated with the Qur'an Surah An Naml verse 16.
Based on the preliminary study results, information was obtained that students' creative thinking skills were still low (Praptiwi, et al., 2021). The implementation of E-Comic is expected to produce students' creative thinking skills. The novelty in this research is to see the potential for developing electronic comics that will be included in a webtoon line associated with daily problems and integrated with Islamic values. Based on this background, research on the development of problem-based learning-based EComic media that integrates Islamic values is important. Therefore, the purpose of this study was to determine the effectiveness of electronic comic media based on problem-based learning integrated with Islamic values to improve students' creative thinking skills.

\section{Method}

This study uses a Research and Development $(R \& D)$ approach using the ADDIE (Analysis, Design, Development, Implementation, and Evaluation). The subjects in this study were students of class VIII C and VIII D of SMP N 3 Watumalang and class VIII A and VIII B of SMP IT Permata Hati, as many as 90 students. This research was conducted from July to August 2021. The data collection technique used research instruments with quantitative data analysis. The data collection instrument was by giving essay questions in the form of a creative thinking ability test. Creative thinking consists of four indicators, namely fluency (fluency), flexibility (flexible thinking), originality (original thinking), and elaboration (thinking in detail) (Batlolona et al., 2019; Jankowska et al., 2019). The ability to think creatively in this study was measured by giving essay questions in the form of a creative thinking ability test validated before being tested. The questions that have been tested are analyzed to meet the criteria for differentiating power, validity, reliability, and level of difficulty. Fourteen questions about the ability to think creatively meet the requirements to measure students' creative thinking skills on vibration, waves, and sounds in everyday life. At the beginning of the study, a pretest was carried out, then the learning used E-comic media, and at the end of the lesson, a posttest was carried out. The analysis of creative thinking skills by calculating the $\mathrm{N}$-gain and the significance test was carried out using an average difference test through a t-test with the help of SPSS.

\section{Result and Discussion}

Creative thinking skills are the ability to use the mind to come up with new ideas in real or abstract terms (Saptenno, et al., 2019). Creative thinking can 
enable one to relate problems from different perspectives and find unique solutions (Habibi, et al., 2020). In this study, the students' creative thinking ability consisted of the pre-action (pretest) and postaction (posttest) creative thinking abilities. The preaction analytical ability (pretest) is carried out before students are given action to know the students' initial skills before being given measure. Based on research data on the creative thinking ability of students at SMP $\mathrm{N} 3$ Watumalang in the pretest activity, there were $3.45 \%$ of students achieved the minimum completeness criteria of 66 on the fluency indicator, $10 \%$ on the flexibility indicator, $7 \%$ on the originality indicator, and $10.34 \%$ on the elaboration indicator. SMP IT Permata Hati students in the pretest activity there were $3.13 \%$ of students who achieved the minimum completeness criteria of 75 on the fluency indicator, $9.38 \%$ on the flexibility indicator, $9.38 \%$ on the originality indicator, and $3.13 \%$ on the elaboration indicator. The creative thinking ability of students in the pretest activity has not reached $100 \%$ because students have not received the previous learning materials.

In the posttest activities from both schools, 100\% of students achieved completeness scores on the indicators of fluency, flexibility, and elaboration. In the originality indicator, $96.55 \%$ of students of SMP N 3 Watumalang achieved completeness scores, while at SMP IT Permata Hati, there were $100 \%$ of students who completed this indicator. The data obtained were tested for normality using the Shapiro-Wilk test in SPSS before the T-test was performed. The results of the normality test are presented in Table 1.

Table 1. Normality Test Result

\begin{tabular}{lll}
\hline Test & $\begin{array}{l}\text { Kolmogrof- } \\
\text { Smirnov Z score }\end{array}$ & Information \\
\hline Pretest VIII A & 0.185 & Normal distribution \\
Posttest VIII A & 0.143 & Normal distribution \\
Pretest VIII B & 0.203 & Normal distribution \\
Posttest VIII B & 0.153 & Normal distribution \\
Pretest VIII C & 0.166 & Normal distribution \\
Posttest VIII C & 0.163 & Normal distribution \\
Pretest VIII D & 0.144 & Normal distribution \\
Posttest VIII D & 0.134 & Normal distribution \\
\hline
\end{tabular}

Based on the normality test results of the data in Table 1. all data are normally distributed, so the assumption of normality in the use of the paired sample t-test has been met. Paired sample test to find out the difference between the average pretest and posttest is really real or not, which is done by each indicator of creative thinking, namely fluency, flexibility, originality, and elaboration. The results of the paired sample t-test are presented in the description of the achievement of creative thinking skills for each indicator of students at SMP N 3 Watumalang Table 2 and SMP IT Permata Hati in Table 3.

Table 2. Description of Students' Creative Thinking Ability at SMP N 3 Watumalang

\begin{tabular}{|c|c|c|c|c|c|c|}
\hline \multirow{3}{*}{$\begin{array}{l}\text { Indicator of Creative Thinking } \\
\text { Ability }\end{array}$} & \multicolumn{6}{|c|}{ Students' Creative Thinking Ability (KKM=66) } \\
\hline & \multicolumn{2}{|c|}{ Pretest $(\mathrm{N}=58)$} & \multicolumn{2}{|c|}{ Posttest $(\mathrm{N}=58)$} & \multirow{2}{*}{$\mathrm{T}$ test } & \multirow{2}{*}{ Sig. } \\
\hline & $\bar{X}$ & SD & $\bar{X}$ & SD & & \\
\hline Fluency & 6.97 & 2.89 & 16.66 & 1.08 & -37.527 & 0.00 \\
\hline Flexibility & 6.86 & 2.01 & 12.93 & 0.72 & -31.372 & 0.00 \\
\hline Originality & 6.03 & 2.22 & 12.71 & 0.77 & -32.108 & 0.00 \\
\hline Elaboration & 7.45 & 2.80 & 16.76 & 0.99 & -35.895 & 0.00 \\
\hline
\end{tabular}

Table 3. Description of the Creative Thinking Ability of SMP IT Permata Hati students

\begin{tabular}{|c|c|c|c|c|c|c|}
\hline \multirow{3}{*}{$\begin{array}{l}\text { Indicator of Creative Thinking } \\
\text { Ability }\end{array}$} & \multicolumn{6}{|c|}{ Students' Creative Thinking Ability $(\mathrm{KKM}=66)$} \\
\hline & \multicolumn{2}{|c|}{ Pretest $(\mathrm{N}=58)$} & \multicolumn{2}{|c|}{ Posttest $(\mathrm{N}=58)$} & \multirow{2}{*}{$\mathrm{T}$ test } & \multirow{2}{*}{ Sig. } \\
\hline & $\bar{X}$ & SD & $\bar{X}$ & SD & & \\
\hline Fluency & 7.66 & 3.98 & 17.25 & 1.29 & -16.794 & 0.00 \\
\hline Flexibility & 7.22 & 2.62 & 13.53 & 0.95 & -17.248 & 0.00 \\
\hline Originality & 7.09 & 2.96 & 13.47 & 0.95 & -15.999 & 0.00 \\
\hline Elaboration & 8.94 & 3.54 & 17.16 & 1.08 & -18.237 & 0.00 \\
\hline
\end{tabular}

Based on Table 2 and Table 3, there was an increase in the average creative thinking ability score of students at SMP N 3 Watumalang and SMP IT Permata Hati on each indicator. In Table 2. there is an increase in the average score of creative thinking skills of SMP N 3 Watumalang students on the fluency indicator of 9.69 from the average acquisition of 6.97 pretests and posttest 16.66 , the flexibility indicator of 6.07 from the average acquisition of 6.86 pretests and posttest 12.93, the originality indicator of 6.68 from the average acquisition of 6.03 pretest and 12.71 posttests, and the elaboration indicator of 9.31 from the average acquisition of the pretest 7.45 and the posttest 16.76. In Table 3, there is an increase in the average score of creative thinking skills of SMP IT Permata Hati students on the fluency indicator of 9.59 from the 
average acquisition of pretest 7.66 and posttest 17.25, the flexibility indicator of 6.31 from the average acquisition of the pretest 7.22 and the posttest 13.53, the originality indicator of 6.38 from the average acquisition of 7.09 pretest and 13.47 posttest, and the elaboration indicator of 8.22 from the average acquisition of 8.94 pretests and 17.16 posttest.

The average score of students' creative thinking skills at SMP N 3 Watumalang and SMP IT Permata Hati is low, namely the originality indicator (original thinking). Students still find it difficult to answer the pretest questions, are less able to analyze the images that have been presented, so students answer according to the knowledge they have. In posttest activities, students can answer correctly, provide a variety of answers, and think of ways to express their understanding that reflects their original thinking ability. This is following Sugiharto et al. (2020) creative thinking can make students solve problems in their way.

The average score of creative thinking skills on the fluency indicator at SMP N 3 Watumalang and SMP IT Permata Hati has met the complete criteria. The student's ability to answer these questions is good because, based on the data obtained, students can answer the questions presented in fairly long sentences with the accuracy of students' answers. The students' pretest answers were quite right, but they lacked a more in-depth explanation of the concepts related to the questions. In the posttest, students can answer the questions correctly. This is following Fatmawati et al. (2021), students have fluency in thinking in creating many ideas to answer questions.

In the flexibility indicator (think flexible), the average score of students, both students of SMP N 3 Watumalang or SMP IT Permata Hati, also met the complete criteria. At the pretest, students were able to analyze the existing images so that they could answer the question correctly, and at the posttest, students could mention more answers than the pretest. This is following Damayanti et al. (2017) on the ability to think flexibly (flexibility) students can answer varied questions based on their experience during learning.

In the last indicator, namely elaboration, the average score of students at SMP N 3 Watumalang and SMP IT Permata Hati has met the criteria for completeness. Students can answer the pretest questions correctly, while a small portion cannot. This is because students have not been able to add, detail, and expand ideas due to the habit of relying on other friends, so only serious students can answer correctly (Irawati et al., 2019). The students' posttest answers were able to explain in detail the solution to the problem by providing many alternative solutions. This follows Printina (2017) that there is a big influence on learning to use comics on students' ability to develop or detail an idea.

Based on Table 2 and Table 3. it can be seen that the value of significance ( 2 tailed) from the two schools, namely $0.00<0.05$, then $\mathrm{HO}$ is rejected, and $\mathrm{Ha}$ is accepted, so it can be concluded that there is a difference in the average creative thinking ability of the pretest and posttest both at SMP N 3 Watumalang and at SMP IT Permata Hati, which means that there is an effect of using E-Comic media in improving students' creative thinking skills. According to Saputro (2016) students who learn through comics media, discussion activities in groups become more efficient, effective, critical, and creative. Discussion activities in learning are carried out by providing a problem to be solved by students in groups. Students can deliver various solutions to solving the issues presented. This following Herlina \& Qurbaniah (2017), understanding the problems and finding answers with varied strategies is part of thinking creatively. Giving the problem can train students to think creatively (Damayanti, et al., 2017). The improvement of creative thinking ability is also presented in Figure 1 and Figure 2.

Based on Figure 1. the average pretest score of the creative thinking skills of SMP N 3 Watumalang students is 39.04, while the average posttest score is 84.33. In Figure 2. the average pretest score of students' creative thinking skills is 44.15 , while the average posttest score is 87.72 . This shows that E-Comic media is also effective in improving students' creative thinking skills, both at SMP N 3 Watumalang and SMP IT Permata Hati. Pretest and posttest value data were also tested with gain normality (N-gain). The results of obtaining a description of the $\mathrm{N}$-gain for each indicator at the pretest and posttest from the two schools are presented in Table 4.

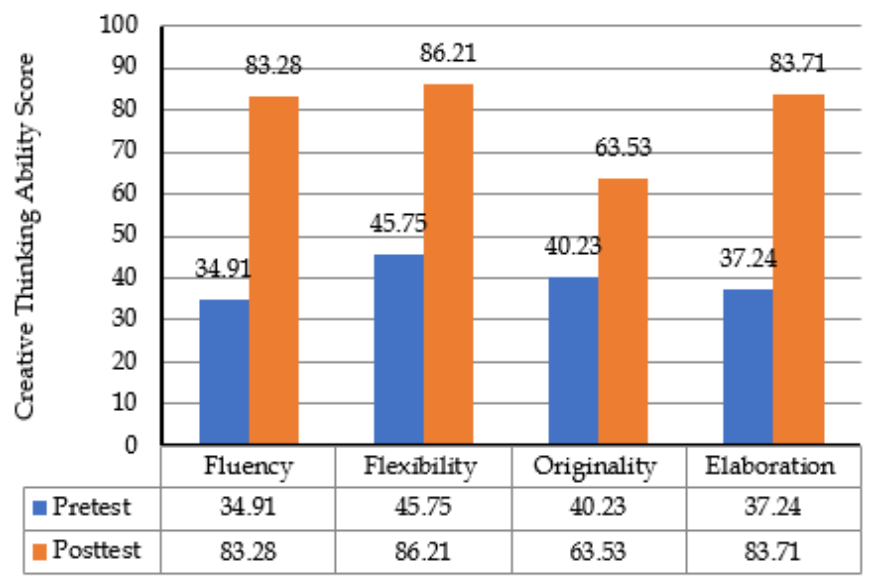

Figure 1. Comparison of the average value of creative thinking skills of SMP N 3 Watumalang students 


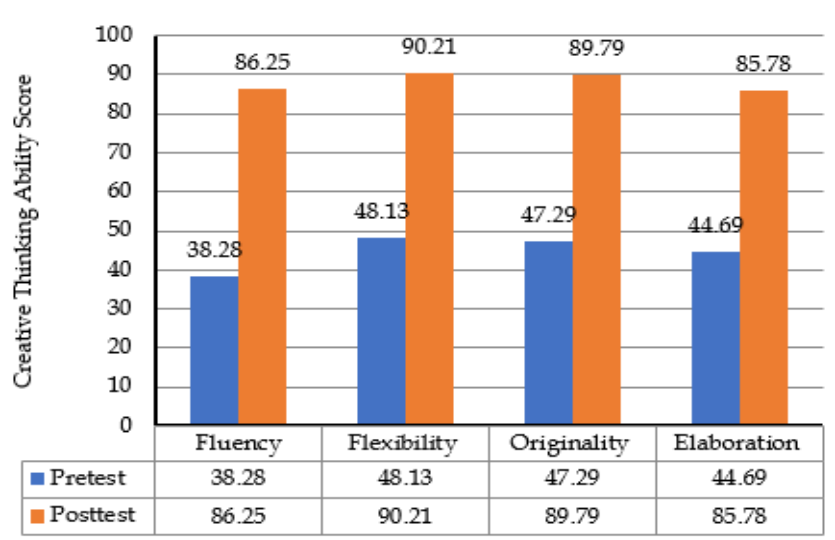

Figure 2. Comparison of the average value of creative thinking skills of SMP IT Permata Hati students

Table 4. Description of the N-gain Pretest and Posttest

\begin{tabular}{lllll}
\hline \multirow{2}{*}{$\begin{array}{l}\text { Indicator of } \\
\text { Creative }\end{array}$} & \multicolumn{2}{l}{ SMP N 3 } & \multicolumn{2}{l}{ SMP IT Permata } \\
Thinking & Watumalang & Hati & \\
\cline { 2 - 5 } Ability & N-gain & Criteria & N-gain & Criteria \\
\hline Fluency & 0.75 & High & 0.78 & High \\
Flexibility & 0.75 & High & 0.83 & High \\
Originality & 0.75 & High & 0.82 & High \\
Elaboration & 0.75 & High & 0.75 & High \\
\hline
\end{tabular}

Based on the gain value description obtained in Table 4 SMP N 3 Watumalang or SMP IT Permata Hati, it can be seen that the gain value for all indicators, namely fluency, flexibility, originality and elaboration, is high. The paired t-test and N-gain test results can be concluded that E-Comic media can improve students' creative thinking skills in learning science at SMP N 3 Watumalang and SMP IT Permata Hati on vibration, waves and sounds in everyday life. This is following Sahida (2019) research that using comics media can improve students' creative thinking skills.

\section{Conclusion}

The results showed that the significance value ( 2 tailed) from the two schools was $0.00<0.05$, then Ho was rejected and Ha was accepted, namely there was a difference in the average creative thinking ability of pretest and posttest both in SMP N 3 Watumalang and in SMP IT Permata Hati, which means that there is an effect of using E-Comic media in improving students' creative thinking skills.

\section{Acknowledgments}

DIPA Semarang State University Number funded this research: SP DIPA-023.17.2.677507/2021 with a Thesis Grant Research Agreement Letter Number 80.19.5/UN37/PPK.5.1/2021. The author would like to thank LP2M Semarang State University for the support and facilities provided.

\section{References}

Affeldt, F., Meinhart, D., \& Eilks, I. (2018). The Use of Comics in Experimental Instructions in a Nonformal Chemistry Learning Context. International Journal of Education in Mathematics, Science and Technology, 6(1), 93-104. https://doi.org/10.18404/ijemst.380620

Batlolona, J. R., Diantoro, M., Wartono, \& Latifah, E. (2019). Creative Thinking Skills Students in Physics on Solid Material Elasticity. Journal of Turkish Science Education, 16(1), 48-61. https://doi.org/10.12973/tused.10265a

Bessette, L. S. (2020). Teaching Comics/Teaching with Comics: A Review of With Great Power Comes Great Pedagogy: Teaching, Learning, and Comic Books. The Comics Grid: Journal of Comics Scholarship, 10(1), 1-5. https://doi.org/10.16995/cg.190

Damayanti, C., Rusilowati, A., \& Linuwih, S. (2017). Pengembangan Model Pembelajaran IPA Terintegrasi Etnosains untuk Meningkatkan Hasil Belajar dan Kemampuan Berpikir Kreatif. Journal of Innovative Science Education, 6(1), 116-128. http://journal.unnes.ac.id/sju/index.php/jise [Indonesian]

Derbel, E. (2019). Teaching Literature through Comics: An Innovative Pedagogical Tool. International Journal of Applied Linguistics and English Literature, 8(1), $54-61$. https://doi.org/http://dx.doi.org/10.7575/aiac.i jalel.v.8n.1p.54

Fatmawati, B., Ariandani, N., \& Sasmita, M. (2021). Student's Creative Thinking Ability with The Lesson Study Design in Biology Content. Jurnal Penelitian Pendidikan IPA, 7(2), 287-292. https://doi.org/10.29303/jppipa.v7i2.708

Fery, M. F., Wahyudin, \& Tatang, H. (2017). Improving Primary Students Mathematical Literacy through Problem Based Learning and Direct Instruction. Educational Research and Reviews, 12(4), 212-219. https://doi.org/10.5897/err2016.3072

Habibi, Mundilarto, Jumadi, J., Gummah, S., Ahzan, S., \& Prasetya, D. S. B. (2020). Project Brief Effects on Creative Thinking Skills Among Low-Ability PreService Physics Teachers. International Journal of Evaluation and Research in Education, 9(2), 415-420. https://doi.org/10.11591/ijere.v9i2.20531

Hamka, D., \& Effendi, N. (2019). Pengembangan Media Pembelajaran Blended Learning Berbasis Edmodo Pada Mata Kuliah Fisika Dasar di Program Studi Pendidikan IPA. Journal of Natural Science and 
Integration,

2(1),

19-33.

https://doi.org/10.24014/jnsi.v2i1.7111

[Indonesian]

Herlina, L., \& Qurbaniah, M. (2017). Analisis Kemampuan Berpikir Kreatif Siswa Pada Materi Virus Kelas X MAS Al-Mustaqim Sungai Raya 2. Jurnal Bioeducation, 4(2), 11-14. https://doi.org/10.29406/663 [Indonesian]

Irawati, I., Anshori, D., \& Sumiyadi, S. (2019). Pengembangan Kreativitas Siswa Melalui Penerapan Model Brainwriting Berbantuan Media Komik. Edusentris, Jurnal Ilmu Pendidikan Dan Pengajaran, 6(2), 95-107. http://ejournal.sps.upi.edu/index.php/edusentri s/article/view/467 [Indonesian]

Jamal, S. N. B., Ibrahim, N. H. B., \& Surif, J. Bin. (2019). Concept Cartoon in Problem-based Learning: A Systematic Literature Review Analysis. Journal of Technology and Science Education, 9(1), 51-58. https://doi.org/10.3926/jotse.542

Jankowska, D. M., Gajda, A., \& Karwowski, M. (2019). How Children's Creative Visual Imagination and Creative Thinking Relate to Their Representation of Space. International Journal of Science Education, 41(8),

1096-1117. https://doi.org/10.1080/09500693.2019.1594441

Kirana, R. P. (2016). Praktik Konsumsi dan Pemaknaan terhadap Komik " Garudayana " Karya Is Yuniarto oleh Anak Muda Penggemar Manga sebagai Agen Pelestarian Wayang. Mozaik Humaniora, 16(1), 70-82. https://ejournal.unair.ac.id/MOZAIK/article/view/10227 [Indonesian]

Koutníková, M. (2018). The Application of Comics in Science Education. Acta Educationis Generalis, 7(3), 88-98. https://doi.org/10.1515/atd-2017-0026

Nahdi, D. S., \& Jatisunda, M. G. (2020). Analisis Literasi Digital Calon Guru SD Dalam Pembelajaran Berbasis Virtual Classroom Di Masa Pandemi Covid-19. Jurnal Cakrawala Pendas, 6(2), 116-123. https://doi.org/10.31949/jcp.v6i2.2133

[Indonesian]

Praptiwi, U. S., Yulianto, A., \& Ellianawati, E. (2021). The Potential of Electronic Media Integrated Islamic Values on Students' Motivation and Creative Thinking Ability. Unnes Science Education Journal, 10(1), 49-58. https://doi.org/10.15294/usej.v10i1.42340

Printina, B. I. (2017). Penggunaan Sumber Belajar Digital Exelsa Moodle dan Komik Toondo Dalam Meningkatkan Kreativitas Belajar Sejarah. Agastya: Jurnal Sejarah Dan Pembelajarannya, 7(2), 57-67. https://doi.org/10.25273/ajsp.v7i2.1489 [Indonesian]

Purwati, N., Zubaidah, S., Corebima, A. D., \& Mahanal,
S. (2018). Increasing Islamic Junior High School Students Learning Outcomes through Integration of Science Learning and Islamic Values. International Journal of Instruction, 11(4), 841-854. https://doi.org/10.12973/iji.2018.11453a

Rina, N., Suminar, J. R., Damayani, N. A., \& Hafiar, H. (2020). Character Education Based on Digital Comic Media. International Journal of Interactive Mobile Technologies, 14(3), 107-127. https://doi.org/10.3991/ijim.v14i03.12111

Sahida, D. (2019). Validitas Handout Berbentuk Komik Fisika Berbasis Problem Based Learning untuk Meningkatkan Keterampilan Berpikir Kreatif Peserta Didik. Jurnal Edu Research Indonesian Institute For Corporate Learning And Studies (IICLS), 1(1),

12-20. https://doi.org/https://doi.org/10.47827/vol1is s1pp12-20 [Indonesian]

Saptenno, A. E., Tuaputty, H., Rumahlatu, D., \& Papilaya, P. M. (2019). The Improvement of Learning Motivation and Creative Thinking Skills of Senior High School Students Through Modified Problem Based Learning Model. Journal for the Education of Gifted Young Scientists, 7(4), 11751194. https://doi.org/10.17478/jegys.597519

Saputro, A. D. (2016). Implementasi Media Pembelajaran Komik Islam untuk Meningkatkan Prestasi Belajar dalam Berpikir Kritis Siswa di Sekolah. ULUL ALBAB Jurnal Studi Islam, 17(1), 110-133. https://doi.org/10.18860/ua.v17i1.3264 [Indonesian]

Sugiharto, B., Malinda, E. R., Rosyadi, I., Anggini, M. D., Padmi, N. R. C., \& Evendi, R. (2020). Differences in Creative Thinking Abilities of High School Students from Village and City. Jurnal Penelitian Pendidikan IPA, 7(1), 21-25. https://doi.org/10.29303/jppipa.v7i1.354

Suratno, Komaria, N., Yushardi, Dafik, \& Wicaksono, I. (2019). The effect of using synectics model on creative thinking and metacognition skills of junior high school students. International Journal of Instruction, 12(3), 133-150. https://doi.org/10.29333/iji.2019.1239a

Toh, T. L., Ho, S. Y., Cheng, L. P., Jiang, H., \& Lim, K. M. (2017). Using Comics in Teaching Mathematics. Proceedings of the 41st Conference of the International Group for the Psychology of Mathematics Education, 1, 277. https://repository.nie.edu.sg/handle/10497/190 11

Yuliana, Siswandari, \& Sudiyanto. (2017). Pengembangan Media Komik Digital Akuntansi Pada Materi Menyusun Laporan Rekonsiliasi Bank Untuk Siswa Smk. Jurnal Pendidikan Dan Kebudayaan, 2(2), 135-146. [Indonesian] 